\title{
Partial sight and blindness in children of the 1970 birth cohort at 10 years of age
}

\author{
S L STEWART-BROWN AND M N HASLUM \\ From the Department of Child Health, University of Bristol
}

SUMMARY The prevalence and causes of partial sight and blindness (best corrected distant visual acuity of $6 / 24$ or less) have been studied in a nationally representative sample of 1500010 -year-old children. The prevalence of blindness (acuity $<6 / 60$ ) was between $3 \cdot 4$ and 4.0/10 000. All these children had been registered as blind; less than half were in schools for the blind, the remainder were all in other special schools. The prevalence of partial sight (acuity $\leqslant 6 / 24 \geqslant 6 / 60$ ) was between 5.4 and $8.7 / 10000$; less than half of these children were in schools for the visually handicapped or partially sighted; most were in ordinary schools; half were neither registered as partially sighted nor ascertained as in need of special education for visual handicap. The most common cause of partial sight or blindness in this cohort was congenital cataract; the second most common was congenital nystagmus. The study identified a number of children whose best acuity on examination was $6 / 24$ or less who had either no ophthalmological diagnosis or who had been diagnosed as suffering from a refractive error. These children have been included in the study because at the time of the survey they had either not been prescribed spectacles or they had spectacles which they were not wearing; the functional visual level of these children was therefore equivalent to that of those defined as partially sighted.

Information about the prevalence of partial sight and blindness in childhood has been derived principally from two sources. The Department of Health and Social Security (DHSS) collects data from the blind and partially sighted registers of local social services departments, and the Department of Education and Science (DES) collects data about children in special schools for the blind and partially sighted.

DHSS registration data have been the principal source of information for these studies. ${ }^{1-5}$ These data include an ophthalmological diagnosis for each individual and therefore permit studies of the incidence of specific ophthalmological conditions. Registration, however, is voluntary, and the completeness of the data derived from this source is frequently questioned. Most of the services provided by county councils for blind and partially sighted children are made available following educational ascertainment. This is in contrast with adults for whom, although not a prerequisite, in practice the key to provision of services is usually registration with the social services department. The incentive to register children as blind or partially sighted may therefore be less than it is for adults.
The data collected by the $\mathrm{DES}^{6}$ on educational ascertainment and placement in special schools for the blind and partially sighted does not provide any information about specific ophthalmological conditions. These data may also be subject to bias resulting from variation in geographical provision of schools for visually handicapped children. The need of a particular child for special education is not rigidly fixed by the degree of impairment. The decision to send a child to a special school is taken on an individual basis by local multidisciplinary teams. These teams take into account social and psychological factors as well as the child's intelligence and visual impairment. The decision involves some value judgements on the part of the individuals comprising the team, and these also may vary in different parts of the country.

Specific epidemiological surveys of visual impairment in defined geographical populations are being undertaken for adults in this country ${ }^{7}$ and have been undertaken abroad. ${ }^{89}$ These surveys are expensive and time consuming to carry out. Because the prevalence of blindness in children is considerably lower than it is in adults, epidemiological surveys in 
this age group are even more expensive. One of the studies in the United States ${ }^{8}$ included children in its sample, but the data from this study on the prevalence of blindness and partial sight in children are limited in value by the small sample size $(2000)$.

In the absence of specific epidemiological studies of ophthalmological disease in children, general surveys of childhood impairment such as the 1970 Birth Cohort Study can provide a reasonable yardstick for measuring the completeness of both registration and educational ascertainment. Although the number of children with blindness and partial sight is relatively low, even in this large cohort of 15000 children, the opportunity which the cohort provides of examining the relation between registration, degree of impairment, educational ascertainment, and ophthalmological diagnoses in a nationally representative sample of 10 -year-old children is valuable.

\section{Methods}

The 1970 Birth Cohort Study began in 1970 with a survey of children born in the United Kingdom in the week 5-11 April. An estimated $97 \%$ of all births were studied.

Children born during that week and living in England, Wales or Scotland were retraced and surveyed in 1975 and again in 1980. In the latter study, an estimated $93 \%$ of survivors of the original cohort were contacted. Any child born in the survey week was included regardless of whether they had taken part in the birth or five year studies. The sample therefore includes children who had migrated into Great Britain since birth and excludes emigrants.

There were two distinct aspects to the ten year survey: a health aspect and an educational aspect. The health side of the study included a medical examination of each child carried out by clinical medical officers and a scrutiny of the child's school medical records.

Corrected and uncorrected monocular distant visual acuities were measured during the medical examination. Detailed instructions were issued with the medical questionnaires about the importance of placing the child at $20 \mathrm{ft}(6.0 \mathrm{~m})$ from the chart, good lighting, and the complete occlusion of the eye not being tested. Clinical medical officers were instructed to use a Snellen chart if this was available. The use of alternative charts was recorded. Information on this aspect of the survey has been presented elsewhere. ${ }^{10}$

Clinical medical officers were asked to record the presence of any abnormal condition affecting the children's eyes, taking both their own examination and the school medical records into account. They were also asked whether a decision had been reached by the local education authority as to whether the child was in need of special education because of impaired vision (forms 4HP or SE2/3).

In the educational part of the study each child's class teacher administered a series of educational tests including tests of reading, spelling, and mathematics. Any child who was unable to complete these tests, for whatever reason, and also all children whose educational scores fell in the lowest $10 \%$ were issued with a special educational test pack. As part of this detailed survey of children with educational difficulties, teachers answered a questionnaire about the children's special needs, including a specific question about vision.

The records of the following three groups of children were studied in detail:

1 children whose best corrected monocular distant visual acuity was $6 / 24$ or less;

2 children said to have ophthalmological conditions capable of causing partial sight or blindness;

3 children on whom health data were not collected but for whom a special educational pack had been issued in which teachers had identified vision as problem.

INFORMATION ON REGISTRATION OF CHILDRENO Questionnaires were sent to the social services department of the county council relevant to the 19800 address of each child whose best corrected visuak acuity was $6 / 24$ or worse and for whom there was an ophthalmological diagnosis campatible with this degree of impairment. The questionnaire enquired whether there was any record of that child on the register; for children who had been registered it asked for the date of registration, the type of registration (blind or partially sighted), and the ophthalmological diagnosis. Questionnaires were returned for all children.

REPRESENTATIVENESS OF SAMPLE A total of 14907 children were surveyed in the ten year study. Health data were obtained on 13871 children, and 12853 children had their distant visual acuity recorded satisfactorily; 12905 children completed educational tests.

All the children who completed the educational tests had to be able to read N12 print to do so. We have therefore made the assumption that there were no partially sighted or blind children in the group who did not complete the health survey but did complete the standard educational tests. Among the few children who required special educational tests and did not participate in the health side of the study there were only three for whom teachers reported visual impairment. Each of these three children was said to have adequate vision with glasses. 
Table 1 Children with severe visual impairment in the 1970 birth cohort

\begin{tabular}{|c|c|c|c|c|c|c|}
\hline $\begin{array}{l}\text { Case } \\
\text { No. }\end{array}$ & $\begin{array}{l}\text { Ophthalmological } \\
\text { condition }\end{array}$ & $\begin{array}{l}\text { Associated } \\
\text { impairment }\end{array}$ & $\begin{array}{l}\text { Best eye } \\
\text { corrected } \\
\text { acuity }\end{array}$ & $\begin{array}{l}\text { Blind or partially } \\
\text { sighted register } \\
\text { date/description }\end{array}$ & $\begin{array}{l}\text { Educationally } \\
\text { ascertained for } \\
\text { visual handicap }\end{array}$ & Schooling \\
\hline \multicolumn{7}{|c|}{ (1a) Children whose visual acuity was $<6 / 60$} \\
\hline 1 & $\begin{array}{l}\text { Bilateral congenital } \\
\text { cataracts, aniridia, } \\
\text { glaucoma }\end{array}$ & ESN(S) & & $\begin{array}{l}\text { Yes } \\
1979 \\
\text { Blind }\end{array}$ & Yes & $\begin{array}{l}\text { ESN(S) } \\
\text { school }\end{array}$ \\
\hline 2 & $\begin{array}{l}\text { Optic atrophy } \\
\text { central blindness }\end{array}$ & $\begin{array}{l}\text { Encephalocele, } \\
\text { microcephalic, } \\
\text { spastic } \\
\text { quadriplegia, } \\
\text { ESN(S) }\end{array}$ & & $\begin{array}{l}\text { Yes } \\
1973 \\
\text { Blind }\end{array}$ & No & $\begin{array}{l}\text { ESN(S) } \\
\text { school }\end{array}$ \\
\hline 3 & $\begin{array}{l}\text { Retrolental } \\
\text { fibroplasia } \\
\text { Phthisis bulbi } \\
\text { Rubella syndrome } \\
\text { Microphthalmus }\end{array}$ & $\begin{array}{l}\text { ESN(M) } \\
\text { partial } \\
\text { hearing, } \\
\text { cerebellar- } \\
\text { ataxia }\end{array}$ & & $\begin{array}{l}\text { Yes } \\
1971 \\
\text { Blind }\end{array}$ & Yes & $\begin{array}{l}\text { School } \\
\text { for } \\
\text { multiply } \\
\text { handicapped }\end{array}$ \\
\hline 4 & Lebers optic atrophy & None & & $\begin{array}{l}\text { Yes } \\
1971 \\
\text { Blind }\end{array}$ & Yes & $\begin{array}{l}\text { School for } \\
\text { blind }\end{array}$ \\
\hline 5 & $\begin{array}{l}\text { Bilateral } \\
\text { retinoblastoma }\end{array}$ & None & & $\begin{array}{l}\text { Yes } \\
1979 \\
\text { Blind }\end{array}$ & Yes & $\begin{array}{l}\text { School for } \\
\text { blind }\end{array}$ \\
\hline \multicolumn{7}{|c|}{ (Ib) Children whose convected visual acuity was $\geqslant 6 / 60 \leqslant 6 / 24$} \\
\hline 1 & $\begin{array}{l}\text { Bilateral congenital } \\
\text { cataracts }\end{array}$ & None & $6 / 24$ & NR & Yes & $\begin{array}{l}\text { Visually } \\
\text { handicapped }\end{array}$ \\
\hline 2 & $\begin{array}{l}\text { Bilateral congenital } \\
\text { cataracts }\end{array}$ & None & $6 / 24$ & NR & No & $\begin{array}{l}\text { Ordinary } \\
\text { school }\end{array}$ \\
\hline 3 & $\begin{array}{l}\text { Bilateral congenital } \\
\text { cataracts }\end{array}$ & None & $6 / 24$ & NR & No & $\begin{array}{l}\text { Ordinary } \\
\text { school }\end{array}$ \\
\hline 4 & Congenital nystagmus & None & $6 / 24$ & NR & Yes & $\begin{array}{l}\text { Visually } \\
\text { handicapped } \\
\text { school from } \\
\text { September } 81\end{array}$ \\
\hline 5 & Congenital nystagmus & None & $6 / 36$ & $\begin{array}{l}\text { Yes } \\
1975 \\
\text { Partially sighted }\end{array}$ & Yes & $\begin{array}{l}\text { Partially } \\
\text { sighted } \\
\text { school }\end{array}$ \\
\hline 6 & Retinochoroiditis & $\begin{array}{l}\text { Mild left } \\
\text { hemiplegia } \\
\text { behaviour } \\
\text { disturbance }\end{array}$ & $6 / 24$ & $\begin{array}{l}\text { Yes } \\
1976 \\
\text { Partially sighted }\end{array}$ & Yes & $\begin{array}{l}\text { School for } \\
\text { delicate and } \\
\text { mildly } \\
\text { maladjusted }\end{array}$ \\
\hline 7 & Cone dysfunction & None & $6 / 36$ & NR & No & $\begin{array}{l}\text { Ordinary } \\
\text { school }\end{array}$ \\
\hline 8 & Macular degeneration & None & $6 / 24$ & $\begin{array}{l}\text { Yes } \\
1979 \\
\text { Partially sighted }\end{array}$ & Yes & $\begin{array}{l}\text { Partially } \\
\text { sighted } \\
\text { school }\end{array}$ \\
\hline \multicolumn{7}{|c|}{ (Ic) Children whose corrected visual acuity was $\geqslant 6 / 60 \leqslant 6 / 24$ who had a non specific ophthalmological diagnosis } \\
\hline 9 & Myopia & $\begin{array}{l}\text { Poor school } \\
\text { performance }\end{array}$ & $6 / 24$ & No & No & $\begin{array}{l}\text { To be } \\
\text { transferred } \\
\text { to ESN } \\
\text { school }\end{array}$ \\
\hline 10 & Squint & $\begin{array}{l}\text { Minimal } \\
\text { cerebal } \\
\text { palsy }\end{array}$ & $6 / 24$ & No & No & $\begin{array}{l}\text { Ordinary } \\
\text { school }\end{array}$ \\
\hline 11 & $\begin{array}{l}\text { Hypermetropia } \\
\text { and squint }\end{array}$ & None & $6 / 24$ & No & No & $\begin{array}{l}\text { Ordinary } \\
\text { school }\end{array}$ \\
\hline
\end{tabular}

$\mathrm{NR}=$ not registered 
Of the children on whom health data were collected who did not have their visual acuity examined, four were said to be blind or partially sighted. For three of these four children visual acuity test results from the most recent ophthalmological clinic visit were recorded in the survey medical questionnaire. These three children were all blind. They were also educationally subnormal. The fourth child was educationally subnormal and was thought to be blind following measles encephalitis at 6 weeks. This child has not been seen by an ophthalmologist and the diagnosis had not been confirmed. He is not included in table 1 but has been included in table 3 in the upper estimate of prevalence of blindness in the cohort.

We have no means of assessing bias due to children who were not surveyed at all at 10 years, but we have no reason to believe that they were either more or less likely to be visually impaired than those who were surveyed.

The denominator used to estimate the prevalence of blindness and partial sight at 10 years of age was all children surveyed at this age (14 907).

\section{Results}

CHILDREN WHOSE BEST CORRECTED MONOCULAR ACUITY WAS $<6 / 60$

There were five children with this level of visual acuity in the cohort. All five had been registered blind, two at 1 year of age, one at 3 years, and two at age 9 . Three of the five were educationally subnormal and two of these three had other additional impairments. The ophthalmological diagnoses in these children are set out in table 1A. Four were blind due to congenital conditions and one following treatment for multifocal bilateral retinoblastomas.

One additional child is included in the upper estimate of the prevalence of blindness in the cohort (table 3); this child was thought to be blind following measles encephalitis at 6 months of age. He had never been ophthalmologically assessed; he attended a school for the educationally severely subnormal $(\mathrm{ESN}(\mathrm{S}))$ and was not registered blind.

CHILDREN WITH SPECIFIC OPHTHALMOLOGICAL DIAGNOSES WHOSE BEST CORRECTED MONOCULAR VISUAL ACUITY WAS $\leqslant 6 / 24$ AND $\geqslant 6 / 60$

There were eight children with this level of acuity for whom specific ophthalmological diagnoses were recorded (table $1 \mathrm{~b}$ ).

In three children the diagnosis was congenital cataract, in two, congenital nystagmus, and in three, partial sight was due to retinal disease. In seven out of the eight children the ophthalmological condition was congenital. Three of these eight children had been registered partially sighted; none had been registered blind. All registrations in this group had taken place after 5 years of age. Two of the three registered children were in schools for the partially sighted, as were two of the five non registered children. Three of the eight children were being educated in ordinary schools. Only one had an associated impairment, and this child had a mild left hemiplegia. Six of these children had an acuity of 6/24 in at least one eye.

CHILDREN WITH A NON-SPECIFIC OPHTHALMOLOGICAL DIAGNOSIS WHOSE BEST MONOCULAR VISUAL ACUITY WAS $\leqslant 6 / 24$

There were a further three children whose corrected visual acuity suggested partial sight; two of these children were said to have refractive errors, and, in one, no diagnosis was offered (table 1c). It is not clear from the survey forms whether these children had been seen by an ophthalmologist. An ophthalmological diagnosis which could explain the degree of visual impairment observed in this survey was not recorded for any of them. Two out of these three had some associated impairment. These three children are included in the upper estimate prevalence of partial sight (table 3 ).

CHILDREN WITH AN UNCORRECTED VISUAL ACUITY OF $\leqslant 6 / 24$ WHOSE CORRECTED VISUAL ACUITY COULD NOT BE DETERMINED

This was numerically the largest group of children (52) with an optimal recorded visual acuity of $\leqslant 6 / 24^{\circ}$ (table 2).

In 14 of these children the visual defect was identified for the first time during the survey medical

Table 2 Other children whose best visual acuity was 6/24 or less

\begin{tabular}{|c|c|c|c|}
\hline & $\begin{array}{l}\text { "Ophthalmological" } \\
\text { diagnosis }\end{array}$ & Number & Comments \\
\hline $\begin{array}{l}\text { Children for whom } \\
\text { spectacles had } \\
\text { been prescibed } \\
\text { but were not } \\
\text { available for } \\
\text { testing }\end{array}$ & $\begin{array}{l}\text { Refractive error } \\
\text { Congenital cataract } \\
\text { Congenital nystagmus } \\
\text { No diagnosis } \\
\qquad \text { Subtotal }\end{array}$ & $\begin{array}{r}14 \\
1 \\
1 \\
17 \\
33\end{array}$ & \\
\hline \multirow[t]{2}{*}{$\begin{array}{l}\text { Children who } \\
\text { had not been } \\
\text { prescribed } \\
\text { spectacles } \\
\text { previously }\end{array}$} & $\begin{array}{l}\text { No diagnosis, } \\
\text { Defect previously } \\
\text { unidentified }\end{array}$ & 14 & $\begin{array}{l}\text { Age last screened } \\
9 \text { years } 3 \\
8 \text { years } 1 \\
7 \text { years } 5 \\
6 \text { years } 3 \\
5 \text { years } 2\end{array}$ \\
\hline & $\begin{array}{l}\text { No diagnosis } \\
\text { Spectacles awaited } \\
\text { or visited to optician } \\
\text { pending } \\
\begin{array}{r}\text { Subtotal } \\
\text { Total }\end{array}\end{array}$ & $\begin{array}{r}5 \\
19 \\
52\end{array}$ & \\
\hline
\end{tabular}


examination and no diagnosis was available for any of them. All had been screened previously in school, three at 9 years and six between 7 and 8 years.

A further 38 children had defects which had been identified before the survey. Thirty three of these had spectacles but they were not carrying their spectacles with them at the time of the survey medical examination and therefore corrected visual acuity could not be determined. Among this group was one child with congenital cataracts and another with congenital nystagmus; of the total group, 14 were described as having refractive errors and in 17 no diagnosis was available. Five children had had their visual defects identified shortly before the survey and were awaiting optometric examination or optical prescriptions.

Two of this group of 52 children, the child with congenital nystagmus and the child with congenital cataracts, are included in the upper estimate of the prevalence of partial sight (table 3 ).

PREVALENCE OF PARTICULAR OPHTHALMOLOGICAL CONDITIONS.

Congenital nystagmus

A total of 17 children were recorded as showing nystagmus on examination. Three of these children had acuities of $\leqslant 6 / 24$ and have already been described. Ten had acuities of between 6/9 and 6/18 and four had perfect acuity. In the latter group, nystagmus was an incidental finding at the survey medical and none of these children had been seen by ophthalmologists previously. Among the ten children with imperfect acuity nine had had their congenital nystagmus diagnosed by an ophthalmologist (table 4a).

\section{Congenital cataract}

In addition to the four children with acuities of $\leqslant 6 / 24$ who have already been described there were three children with unilateral congenital cataracts. These children all had an acuity of $6 / 6$ in their unaffected eye (table 4b).

Table 3 Prevalence of blindness and partial sight at 10 years of age

\begin{tabular}{llll}
\hline & $\begin{array}{l}\text { Observed } \\
\text { rate } / 10000(n) \\
(95 \% \\
\text { confidence limits) }\end{array}$ & $\begin{array}{l}\text { Registered } \\
\text { children } / \\
10000(n)\end{array}$ & $\begin{array}{l}\text { Children in schools } \\
\text { for blind and } \\
\text { partially sighted } \\
\text { Rate/10 000 (n) }\end{array}$ \\
\hline $\begin{array}{l}\text { Blind } \\
\text { Acuity <6/60) }\end{array}$ & $\begin{array}{l}3.4(5)-4.0(6) \\
(0.0-7.0)\end{array}$ & $3.4(5)$ & $1.3(2)$ \\
$\begin{array}{l}\text { Partial sight } \\
\text { (Acuity } \leqslant 6 / 24 \geqslant 6 / 60)\end{array}$ & $\begin{array}{l}5.4(8)-8.7(13) \\
(1.0-15.0)\end{array}$ & $2.0(3)$ & $2.0(3)$ \\
\hline
\end{tabular}

Optic atrophy

In addition to the one child blind due to Lebers optic atrophy there was one child blind with optic atrophy secondary to an encephalocele and one child with optic atrophy secondary to hydrocephalus whose corrected visual acuity was $6 / 9$ (table $4 c$ ).

\section{Ophthalmic tumours}

In addition to the child with bilateral retinoblastomas one child had had a unilateral retinoblastoma and one child had had an eye enucleated following an angioma of the inner canthus (table 4d).

\section{Other conditions}

There were eight children unilaterally blind following an injury, one child with unilateral blindness

Table 4 Prevalence of specific ophthalmic conditions in the cohort

\begin{tabular}{llll}
\hline Best acuity & $\begin{array}{l}\text { Number of } \\
\text { children }\end{array}$ & $\begin{array}{l}\text { Rate/ } \\
10000\end{array}$ & $\begin{array}{l}\text { Associated } \\
\text { impairment }\end{array}$ \\
\hline
\end{tabular}

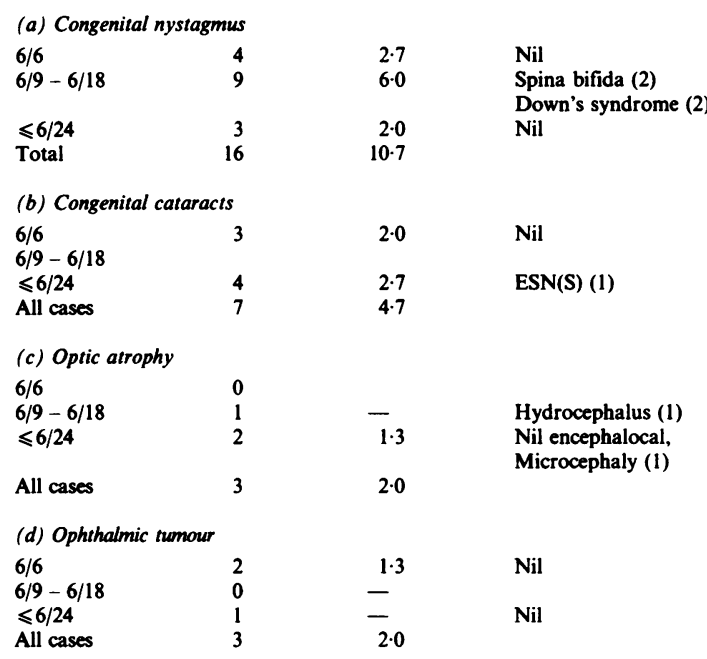

(e) All other specifice ophthalmic conditions

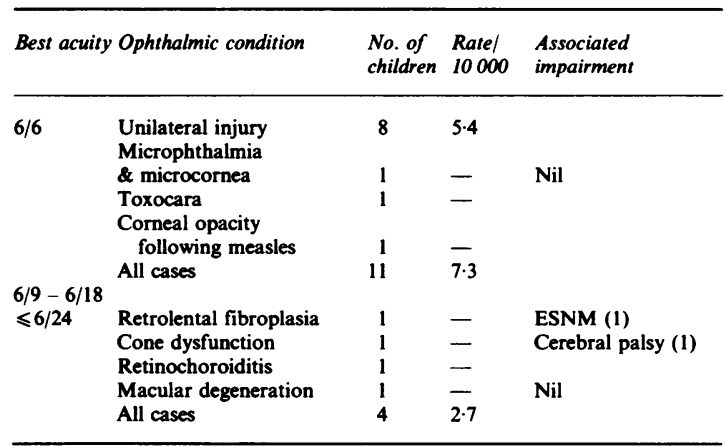


suggestive of toxocara, one with a unilateral corneal opacity following measles, and one with unilateral microphthalmus and microcornea.

\section{Discussion}

DEFINITION OF BLINDNESS AND PARTIAL SIGHT The definitions of both blindness and partial sight have been debated; those most commonly used are based on visual acuity but the ability to see depends also on other aspects of visual function as well as the psychological status and mental ability of the individual. Although these complexities are well recognised, visual acuity remains the best readily available measure for the use of epidemiologists.

The most commonly used definition of blindness in the UK is an acuity of $2 / 60$ or worse. This level of acuity was not recorded in the survey, and we have taken as blind all children who failed to achieve an acuity of $6 / 60$. The most commonly used definition of partial sight is an acuity $\leqslant 6 / 24$.

RELIABILITY OF VISUAL ACUITY MEASUREMENTS

Visual acuities recorded in this survey were measured by clinical medical officers under standard school conditions which are recognised as being less than adequate in many circumstances. Visual acuity measurements made by trained nurses in an ophthalmology clinic have been shown to be relatively unreliable, 11 and it is unlikely that the measurements made for this survey are any more accurate than these. One study on inter-observer reliability in visual acuity measurement ${ }^{8}$ suggested that less experienced observers tend to record better visual acuities than the more experienced. This study suggests that prevalence rates reported here for the 1970 cohort may be conservative. It is important that these potential biases are taken into account in interpreting results from this study.

COMMON CAUSES OF BLINDNESS AND PARTIAL SIGHT IN THIS STUDY

The most common cause of blindness and partial sight in this cohort was congenital cataract; congenital nystagmus was the only other condition responsible for more than one case. These two conditions together were responsible for between one half and two thirds of all cases. However, it is important to note that 14 of the 17 children with congenital nystagmus and three of the eight with congenital cataract had visual acuities of $6 / 18$ or better. The variability in the level of impairment associated with congenital nystagmus probably accounts for the wide variation in published estimates of prevalence of the condition. ${ }^{12}$
PREVALENCE OF BLINDNESS

The prevalence of blindness in this cohort was between $3 \cdot 4 / 10000$ and $4 \cdot 0 / 10000$. The $95 \%$ confidence limits, however, are wide because of the small number of blind children in the survey; 3.4/10 000 children had been registered blind. This is slightly higher than the rates published for children aged $5-15$ in the 1960 s $(2 \cdot 1-2 \cdot 6 / 10000)^{2}$ but the difference is not statistically significant. A total of $1 \cdot 3 / 10000$ children were in schools for the blind. This figure agrees closely with that published by the Vernon Committee from DES statistics relating to $1971 .^{6}$

All children who had been diagnosed by ophthalmologists as blind had been registered as such; three out of the four children with congenital conditions had been registered at or before the age of 3 years.

The proportion of blind children in this survey who were $\operatorname{ESN}(\mathbf{S})$ and the proportion who had other additional impairments agrees reasonably well with that published from a specific survey of children in special schools in 1973 and $1974 .^{5}$

\section{PREVALENCE OF PARTIAL SIGHT}

The definition of partial sight used in this study is more controversial than that of blindness; and although the lower estimate of the prevalence $(5 \cdot 4 / 10000)$ is reliable, the upper estimate $(8 \cdot 7 / 10000)$ is less reliable; as for blindness, the $95 \%$ confidence intervals are quite wide (table 3). In the absence of a detailed ophthalmological examination of all 52 children whose uncorrected vision was $\leqslant 6 / 24$ but who could not be examined with spectacles, it is possible to provide only a conservative upper estimate. Only two children in this group have been included in the upper estimate and both of these had ophthalmological conditions which were unlikely to have been significantly improved with spectacles.

Two children per 10000 had been registered as partially sighted. This figure is not significantly different from that published from the partially sighted register data in the $1960 \mathrm{~s}(2 \cdot 8-3 \cdot 3 / 10000) .{ }^{2} \mathrm{We}$ might have expected the prevalence figure from this cohort, however, to be lower than that from registration data for the following reason: an analysis of the partially sighted register ${ }^{5}$ has shown that as many as $16 \%$ of registered children have acuities of $6 / 18$ or better. Such children would not have been included in the current study because their acuity level would have fallen outside the range specified.

The survey figure for children in schools for the partially sighted at 10 years of age was $2 \cdot 0 / 10000$. This figure is not significantly different from that published from DES statistics in $1971 .^{6}$

Children registered as partially sighted and children in schools for the partially sighted represented 
between one half and one quarter of all children with acuity levels of $\leqslant 6 / 24$. All the children who had been registered partially sighted were in special schools but not all children ascertained as in need of special education for partial sight were registered.

PARTIALLY SIGHTED CHILDREN WITHOUT A SPECIFIC OPHTHALMOLOGICAL DIAGNOSIS

The identification of a large number of children who had no specific ophthalmological diagnosis but who were unable to achieve an acuity of $6 / 18$ or more was an unexpected finding. The majority of these children did have spectacles but were not wearing them at the time of the survey medical examination and therefore could not be tested with them in place. For most of these children $(73 \cdot 1 \%)$ the visual defect had been identified prior to the survey medical examination; in only 14 was the visual defect a new finding. Most of the latter children had had their vision screened at school within the last three years.

There are several possible explanations for this finding, all of which warrant further investigation. One of the most likely explanations is that visual acuity had been inaccurately measured in these children, and thus their true acuity was $6 / 18$ or better. If this was the case, and we assume that all children in tables $1 \mathrm{c}$ and 2 had inaccurate acuity measurements, then we can calculate that the specificity of visual acuity testing in schools for the detection of partial sight or blindness is less than $25 \%$. This is exceedingly low and calls into question the value of school vision screening as currently practised.

If we allow that the visual measurements on these 52 children were accurate, the most likely ophthalmological diagnosis would have been refractive error. The latter should all be correctable with spectacles. There are then two possible explanations for the findings that 33 children with an acuity of $\leqslant 6 / 24$ had spectacles but did not routinely wear them. First, these children may have had an incorrect prescription which failed to improve their visual acuity; or, second, they may have had appropriate spectacle corrections of which they chose not to make use. Both possibilities warrant further study.

The third possibility-that these children had accurate visual acuity measurements but that the cause of their impairment was not a simple refractive error-must also be considered. This explanation would lead to the unlikely conclusion that the prevalence of severe visual impairment in 10-year-old children could be as high as 32.9/10 000 and that in four fifths of children with this level of acuity the underlying condition had not been diagnosed in spite of multiple school vision screening tests.

Whatever its explanation, this finding raises some serious questions about currently available services for the detection and treatment of visual abnormality in school children. Either large numbers of children with very abnormal vision are being missed, or large numbers of children without gross abnormality are being incorrectly screened as positive. Such children only come to light in epidemiological studies; from both an ethical and economical standpoint they warrant further investigation.

The health aspect of the 10-year follow-up was funded jointly by a grant from the Department of Health and Social Services and the Joseph Rowntree Memorial Trust to the Department of Child Health, University of Bristol. The educational aspect was funded by a grant from the Department of Education and Science. Additional financial support was received from the National Institute of Health, USA. We gratefully acknowledge the widespread cooperation of all specialists in community medicine, clinical medical officers, and health visitors who made this study possible. In addition, we thank all participating children and their parents. The editing and coding of this study was carried out by a dedicated body of clerical staff, some of whom were employed on a programme funded by the Manpower Services Commission.

\section{References}

${ }^{1}$ Sorsby S. The incidence and causes of blindness in England and Wales, 1948-62, Rep Public Health Med Subj, 1966, No. 114. London: HMSO.

2 Sorsby S. The incidence and causes of blindness in England and Wales, 1963-68, Rep Public Health Med Subj, 1972, No. 128. London: HMSO.

${ }^{3}$ Ghafour IM, Allan D, Foulds W S. Common causes of blindness and visual handicap in the west of Scotland, $\mathrm{Br}$ J Ophthalmol, 1983, 67: 209-13.

4 Taylor D. The prevalence of visual handicap in children in England and Wales. Child Care, Health and Development, 1975, I: 291-7.

${ }^{5}$ Fine SR. Incidence of visual handicap in childhood. 1975 In Visual handicap in children, Ed. Smith V, Keen J. Havenham Press, Suffolk: Spastics International Medical Publishers.

${ }^{6}$ Department of Education and Science. The education of the visually handicapped (The Vernon Report) 1972, London: HMSO.

${ }^{7}$ Cullen T. City Eye Study, Department of Environmental and Preventive Medicine, St. Bartholomew's Hospital, University of London. Unpublished.

${ }^{8}$ US Department of Health, Education and Welfare. Monocular visual acuity of persons 4-74 years, USA 1971-1972 HRA Series II, 1977, No. 201 DHEW Pub No. (HRA) 1977-1646.

${ }^{9}$ Kaha HA, et al. The Framingham Eye Study Am J Epidemiol, 1977, 106: 17-32.

${ }^{10}$ Stewart-Brown S, Butler NR. Visual acuity in a national sample of ten year old children, $J$ Epidemiol Community Health, 1985, 39: 107-12.

11 Gibson RA, Sanderson HF. Observer variation in ophthalmology, Br J Ophthalmol, 1980, 64: 457-60.

12 Abadi RV, Carden D, Simpson J. A new treatment for congenital nystagmus. Br J Ophthal, 1980, 64: 2-6. 